\title{
Above- and belowground linkages shape responses of mountain vegetation to climate change
}

Frank Hagedorn ${ }^{1 *}$, Konstantin Gavazov $^{1+}$, Jake M. Alexander ${ }^{2+}$

${ }^{1}$ Swiss Federal Institute for Forest, Snow and Landscape Research WSL, Zürcherstrasse 111, 8903 Birmensdorf, Switzerland

${ }^{2}$ Institute of Integrative Biology, ETH Zurich, Universitätstrasse 16, 8092 Zürich, Switzerland

* corresponding author: frank.hagedorn@wsl.ch

${ }^{\dagger}$ Equal contribution to authorship

This document is the accepted manuscript version of the following article: Hagedorn, F., Gavazov, K., \& Alexander, J. M. (2019). Above- and belowground linkages shape responses of mountain vegetation to climate change. Science, 365 (6458), 1119-1123. https://doi.org/10.1126/science.aax4737 


\section{Abstract}

2 Upwards shifts of mountain vegetation lag behind rates of climate warming, partly related to

3 interconnected changes belowground. Here, we unravel above and belowground linkages by

4 drawing insights from short-term experimental manipulations and elevation gradient

5 studies. Soils will likely gain carbon in early successional ecosystems, while losing carbon as

6 forest expands upwards, and the slow high-elevation soil development will constrain

7 warming-induced vegetation shifts. Current approaches fail to predict the pace of these

8 changes, and how far they will be modified by interactions among plants and soil biota.

9 Integrating mountain soils and their biota into monitoring programs, combined with

10 innovative comparative and experimental approaches, will be crucial to overcome the

11 paucity of belowground data and to better understand mountain ecosystem dynamics and

12 their feedbacks to climate. 


\section{Introduction}

The distinct zonation of mountain vegetation has inspired generations of biologists interested in how environmental - and especially climatic - variation shapes ecosystem structure and function $(1,2)$, and mountain plants have served as bioindicators for the impacts of climate changes over the last century (3). Despite comprising only $12 \%$ of the terrestrial surface, mountains host high levels of biodiversity and provide crucial ecosystem services (e.g. carbon storage, raw material provisioning, natural hazard protection, water reservoirs) with far reaching effects on lowland ecosystems and global climate (4). Mountain ecosystems are experiencing especially strong climate warming (5). The expected warming of $2-4^{\circ} \mathrm{C}$ this century (5) could extend vegetation zones and the thermal limits of plant life upwards by as much $300-600 \mathrm{~m}$ in elevation, with profound consequences for ecosystem functioning (Figure 1). But while responses of mountain vegetation have been widely studied aboveground, there are parallel changes occurring in the "dark" side of ecosystems belowground, where plant roots and their associated microbial communities form a complex but largely unknown world in the soil. Alpine soils above treeline store more than $90 \%$ of ecosystem carbon (4), and thus even small changes in soil carbon storage will have a large effect on the overall climate balance of mountain ecosystems (6). Soils also provide nutrients to sustain plant growth, which is strongly nutrient-limited in mountain plants $(7,8)$, and so changes in nutrient availability and in soil microbial community composition could represent a strong modifier of vegetation shifts in a warming climate (9). In our review, we show how plant communities, soils and their associated microorganisms are interlinked in mountain ecosystems, identify how belowground ecosystems might respond to vegetation shifts in a changing climate and, finally, indicate how short- and long-term changes in carbon and nutrient cycling may feedback to climate and modify vegetation shifts. 


\section{Elevation shifts of mountain vegetation}

Mountains have characteristic vegetation belts transitioning from forest, heathland and alpine grassland up to the nival zone with a permanent snow cover (Figure 2). While vegetation forms a mosaic controlled by parent materials, soil development and topography at the local scale, climate conditions are of primary importance for the formation of distinct vegetation belts along mountain slopes, such as at treeline (10-12) and at the upper limit of vascular plant life (13). Temperatures belowground are more buffered than aboveground and remain lower for the duration of the short vegetative season, critically limiting plant growth below $\sim 5^{\circ} \mathrm{C}(4,14)$. Due to their climate sensitivity, shifts in the distributions of individual plant species and vegetation types to higher elevations therefore provide evidence for the impact of climate warming on natural ecosystems worldwide $(3,15)$. Revisiting Humboldt's plant surveys documents an upward migration of c. 250 m over 215 years (2). The colonization of new species has accelerated this century on European mountains (3), and even the upper limit of continuous plant life has advanced at high elevations, such as in the NW Himalaya (13), in striking synchrony with increased rates of climate warming (3). Treelines are expanding at $52 \%$ of 166 sites around the world (Figure 1, 12), and available evidence also suggests that shrublines are advancing upwards in the northern hemisphere, consistent with increasing shrub encroachment in tundra vegetation at high latitudes (16).

Although upward elevational shifts provide strong evidence for the impact of climate change on mountain vegetation, they are also remarkably heterogeneous. On average, rates of range expansion lag significantly behind advances in isotherms on mountains $(2,15)$, and average values conceal huge variation in the rates, and even directions, of range changes. This variation can be explained by a complex suite of interacting drivers of species' 
distributions and abundances, including variation in species' demography and physiological responses to changing climate, interactions among species, and the physical environment (17). Notably, climate warming effects on vegetation are frequently superimposed by landuse changes in Eurasian mountains and downward range shifts can occur as climate change alters water availability, especially in more arid (18) and subtropical (19) mountain regions.

Interactions at the vegetation-soil interface can play a key role in shaping variation in species' responses to warming. For example increasing canopy cover with shrub and treeline advances shades and cools the soil during the growing season, which is likely to slow further vegetation shifts $(4,10,16)$. Range expansions can also be constrained by insufficient water retention and low nutrient availability due to low organic matter content in poorlydeveloped high-elevation soils (20), while plants that successfully establish at higher elevations tend to be those that can colonize open scree (21). Soil development will therefore be a key factor limiting the expansion of species to higher elevations with climate warming (22), and could explain why diffuse timberlines are more likely to advance, while abrupt ones, that are more constrained by soil development, drought and wind, do not (12).

In addition to physical and chemical properties of the soil, rates of plant range expansion can be influenced by biotic interactions in the soil. Warmer temperatures towards the soil surface might provide shallow-rooted herbs with a competitive advantage over woody plants (14), potentially contributing to negative effects of alpine grassland and shrubby vegetation on tree recruitment (11) and slowing forest expansion. Plants also engage in a multitude of positive and negative, direct and indirect interactions with soil organisms (23). Although evidence from mountain systems is so far limited, changes to plant-soil biota 
interactions are likely to influence plant responses to changing climate (17), similar to their influence on the dynamics of biological invasions.

\section{Belowground impacts of climate change in mountains}

Vegetation shifts are paralleled belowground, where plants and soils interact at time scales ranging from hours to millennia (Figure 3), spanning the extremely rapid transfer of photosynthetic products to roots, mycorrhizal fungi and other root-associated microorganisms, to the formation of soil organic matter (SOM) over thousands of years. Climate change will therefore have short-term effects on ecosystems by modifying above and belowground linkages in current species assemblages, as well as longer-term impacts that unfold as species shift their distributions in response to climate warming. Inference about future climate change impacts therefore requires complementary approaches to study these processes, that have included (i) manipulative experiments identifying short-term effects of climate on the interaction between plants and soils $(24,25)$, and (ii) "space-fortime" substitutions along elevational gradients, which assume that the spatial changes in ecosystem structure and function moving from high to low elevation are analogous to longer-term temporal trajectories of mountain ecosystems under climatic warming $(26,27)$.

\section{Short-term and direct effects of climate warming}

Higher temperatures accelerate the metabolic activity of organisms both above and belowground, which strongly impacts carbon (C) and nutrient cycling. In mountain ecosystems, experimental warming stimulates plant productivity unless water is limiting (9, 
28 , Table S1). Heating soils by $4^{\circ} \mathrm{C}$ at the alpine treeline and in montane forests increased soil $\mathrm{CO}_{2}$ effluxes by $40-50 \%$, resulting from both accelerated rhizosphere activity and enhanced soil C mineralization $(24,29)$. These responses are likely transient as microbial communities acclimate to warmer conditions, without significantly changing their community structure and soils deplete in readily available $C$ until a new quasi-equilibrium is reached (29-31). The magnitude and duration of warming responses vary among studies, but longer-term experiments observed accelerated soil C mineralization for more than a decade $(29,30$, Table S1). Higher $\mathrm{C}$ losses through soil $\mathrm{C}$ mineralization tend to be compensated by increased soil $\mathrm{C}$ inputs from plants, resulting in small net effects on the soil $\mathrm{C}$ balance as compared to the pronounced warming effects on soil C fluxes $(25,32)$. Despite considerable research efforts, there is no consensus on the magnitude of warming effects on soil C storage (25). Soils of cold climates such as at high latitude or elevation seem particularly vulnerable to warming because they contain inherently high $\mathrm{C}$ stocks and high amounts of labile C, potentially promoting strong and sustained soil C losses $(24,29,33)$. However, warming effects are contingent on water availability, and in semi-arid mountains the soil $\mathrm{C}$ balance appears less dependent on projected temperature changes than on variation in the amount and timing of precipitation (34). Impacts of climatic warming is especially large in permafrost soils that only exist above the shrubline in the Alps, but reach down to the subalpine zone in continental mountain ranges at mid and northern latitudes. On the Tibetan plateau, for instance, permafrost collapse has resulted in a $32 \%$ decline in soil $\mathrm{C}$ stocks in surface soils (35), and an alpine tundra meadow with discontinuous permafrost in Colorado was found to represent a substantial net $C$ source to the atmosphere by releasing $C$ from ancient buried soil C (36). 
129 Plant growth in mountain ecosystems is strongly limited by soil nutrients (7), and in 130 particular by nitrogen $(\mathrm{N})(8)$, of which more than $90 \%$ is bound to organic matter. $\mathrm{N}$ 131 availability for plants is therefore predominantly driven by microbial mineralization, at rates 132 that are naturally constrained by low temperatures in mountain ecosystems to less than $2 \%$ 133 of total soil $\mathrm{N}$ per year (37). More rapid processing of soil organic matter (SOM) due to 134 warming therefore enhances $\mathrm{N}$ cycling, approximately doubling the release of plant available $135 \mathrm{~N}$ and thereby stimulating the growth of some plant species $(9,27,38$, Table $\mathrm{S} 1)$. Increased $136 \mathrm{~N}$ contents in foliage, either resulting from higher $\mathrm{N}$ availability or a higher abundance of 137 nitrophilous plants, can promote litter decomposition, further stimulating the release of $\mathrm{N}$ 138 and generating a positive feedback to soil $\mathrm{N}$ availability (39). Conversely, in some cases 139 enhanced plant productivity can bind $N$ in living biomass, decreasing available $N$ (9).

140 Warming-induced changes in $\mathrm{N}$ availability are also reflected in soil microbial communities.

141 Soil warming at treeline led to the proliferation of ectomycorrhizal fungi (ECM) adapted to 142 high $\mathrm{N}$ availability (40), which may have further longer lasting consequences in these 143 ecosystems, due to the importance of mycorrhizal fungi for soil C cycling and plant nutrient 144 supply (41).

146 Longer-term above and belowground linkages

147 Over longer time scales, the upward migration of mountain vegetation impacts the entire 148 soil system. While increasing canopy height caused by shrub and treeline advances cools the 149 soil during the growing period (4), it warms it during winter by promoting the accumulation 150 of an insulating snow cover (16). Higher winter soil temperatures stimulate soil processes 151 driven by microbial communities $(36,42)$, and enhances $\mathrm{N}$ mineralization that stimulates 
152 shrub and tree growth in high elevation and latitude systems (37). On decadal, centennial or

153 even longer time scales, vegetation primarily affects the soil system by its influence on SOM.

154 SOM is of central importance for climate feedbacks, represents a key reservoir for water and

155 nutrients, and serves as a substrate for microbial communities. However, the impact of

156 vegetation has to be disentangled from other key factors affecting SOM - climate and

157 geochemistry - that can be of similar importance $(31,43)$. To better understand how these

158 processes might play out in response to future climate change, we can gain insight from

159 studies of vegetation-soil interactions across elevation gradients, under the assumption that

160 these represent plant-soil systems in quasi-equilibrium with current climate (27).

161 The large reservoir of SOM encompasses a continuum of compounds which can be

162 separated into old mineral-associated organic matter (MOM) that is stabilized through its

163 interaction with mineral surfaces and labile young particulate organic matter (POM),

164 primarily consisting of decomposing plant residues (Figure 3,31 ). In temperate soils, POM

165 contributes only $10 \%$ of total SOM stocks, but high elevation soils typically have POM

166 fractions as high as $30-60 \%$, including organic layers on top of mineral soils $(26,33,44,45)$.

167 On poorly weathered bedrock, SOM can even be entirely comprised of POM. High POM

168 accumulation reflects slow litter decomposition due to low temperatures, the recalcitrant

169 nature of plant residues with high contents of polyphenols (45-47), and the low abundance

170 of soil fauna, especially earthworms, which limits the incorporation of litter into mineral soils

171 (48). Particulate organic matter represents a soil C pool that is highly vulnerable to loss when

172 plant inputs are altered through plant community shifts (e.g. by expansion of broadleaf

173 forests) or when temperature constraints on microbial and faunal decomposition are

174 alleviated by climatic warming. 
175 Along elevation gradients, soil C stocks are very small in early successional alpine ecosystems

176 where low $C$ inputs from plants and slow weathering retard SOM accumulation (Figures 2

177 and $3,49,50)$. Soil C stocks typically peak in high-elevation forests, at treeline or in the shrub 178 zone above, reaching up to $20-30 \mathrm{~kg} \mathrm{C} \mathrm{m}^{-2}$ in the Swiss Alps, Andes, and Himalaya, and then 179 decline in low-elevation forests, which have $5-20 \mathrm{~kg} \mathrm{C} \mathrm{m}^{-2}$ smaller soil C stocks (26, 44, Table $180 \mathrm{~S} 1$ ). This decrease partially offsets $C$ gains with increasing biomass (averaging $12 \mathrm{~kg} \mathrm{C} \mathrm{m}^{-2}$ in 181 Swiss forests), and can be explained by faster litter decomposition, higher litter quality, and 182 a decreasing input of below as compared to aboveground litter (e.g. 51). Moreover, forest 183 trees may release labile root exudates, fuelling microbial metabolism that in turn induces $\mathrm{C}$ 184 losses from older SOM in a process known as priming (6). Shifts in the fungal community 185 from ericoid mycorrhiza and arbuscular mycorrhiza under shrubs and grasses to ECM in 186 forests (Figure 2) may cause further soil C losses through mining for nutrients. In their quest 187 for SOM-bound nutrients, ECM secrete powerful oxidative enzymes to outcompete free188 living saprotrophic fungi and bacteria, which further promotes SOM decomposition (e.g. 41). 189 At the subarctic treeline, soil C stocks were found to decrease by $70 \%$ along transects from 190 ericaceous shrubs to deciduous shrubs and forests (6). The decline was associated with an 191 increasing C turnover and was closely correlated with ECM productivity, consistent with 192 nutrient mining (6).

193 Elevational patterns of vegetation and SOM are partly reflected in soil microbial 194 communities. Microbial biomass and the contribution of fungi as compared to bacteria 195 typically increase from the nival zone to treeline, but decreases in forest at lower elevations $196(26,50,52$, Table S1). But at the species level, elevational patterns in soil microbial diversity 197 are heterogeneous and only weakly related to plant diversity (53). Early successional alpine 198 habitats are an exception. Here, a higher microbial dependence on plant organic inputs 
199

200

201

202

203

204

205

206

207

208

209

210

211

provides for a tighter positive relationship between plant and microbial taxonomic richness $(50,52)$. Nonetheless, elevational turnover in microbial community composition can be pronounced and varies according to plant type (54), suggesting that there will be interdependencies among plant and soil microbial responses to climate warming.

\section{Implications of above and belowground linkages in mountains}

Collectively, the patterns of above and belowground linkages in mountain ecosystems that have been observed from short-term experimental manipulations and across elevation gradients lead to several insights into how mountain vegetation and soil ecosystems might respond to changing climate, which we outline below.

1. Shifts in vegetation and the associated belowground system will feedback to climate warming through their impact on soil $\mathrm{C}$, but this effect will differ between vegetation zones on mountains. Because of the peak in soil C storage and labile POM around treeline, soils are expected to gain $\mathrm{C}$ with advances of alpine grass and heathlands, but are highly vulnerable to $C$ loss when forests shift upwards. The latter might at least partly outweigh the increased C storage in tree biomass. Gradient studies provide no information about how fast these changes could occur, but soil C dynamic is known to follow a "slow in, fast out" principle, with a disparity between the rates of soil $\mathrm{C}$ gains and losses, as observed following land-use change (55). Overall, this pattern suggests that soil carbon will be lost with vegetation shifts in a warming climate, but the rates remain unknown. Studies along glacier forefields lend 
220 support for a slow SOM build-up ( $2 \mathrm{~kg} \mathrm{C} \mathrm{m}^{-2}$ in 100 years), due to slow vegetation

221 succession and low weathering impeding SOM stabilization (49).

222 2. Plant migration and soil development operate at different timescales, such that chemical 223 and physical processes belowground will constrain the rate of vegetation changes in 224 mountains. The slow SOM accumulation and low nutrient availability in early-successional 225 soils will restrict warming-induced shifts for a number of species, especially for those whose 226 thermal tolerance would allow them to advance to high elevations but which require SOM 227 and nutrient rich soils (21). Paleobotanical studies show that time lags between suitable 228 temperatures and upward migration of subalpine forests during the Holocene were as long 229 as 3000-6000 years, possibly due to slow soil development following deglaciation (20). 230 Nonetheless, feedbacks between plants and soil conditions will influence the rate of 231 vegetation change, potentially facilitating plant establishment and growth. For example, 232 SOM accumulation by cushion-forming plants facilitates the establishment of new plants in 233 high alpine ecosystems (56), while snow accumulating around taller plants prevents soils 234 from freezing, which improves $\mathrm{N}$ availability and promotes plant growth $(16,37)$.

235 3. Rhizosphere microbial communities are central to many soil processes and microbial 236 community composition is likely to modulate the responses of mountain vegetation to 237 climate change in both the short and long term. Asynchrony in the rates at which plants and 238 their associated soil biota establish at higher elevations could impact plant population and 239 community dynamics in the longer term (57). For instance, the absence of key mycorrhizal 240 fungi (58) or presence of soil pathogens (59) can limit the range expansions of trees, 241 although the quantitative importance of such effects is poorly understood. 


\section{Conclusions and future prospects}

244 Above and belowground linkages play a central role in the responses of ecosystem processes

245 in mountains to climate warming, but in contrast to well documented shifts in plant

246 assemblages $(2,3)$, changes in belowground systems remain largely unknown. Historically,

247 high-elevation soils have not been analysed quantitatively nor archived, and we still lack

248 basic data on belowground plant productivity, the diversity and functional role of soil

249 microbial communities, nutrient mineralization rates and SOM stocks. To improve our

250 limited understanding of plant-soil interactions in mountains, we need to address the

251 following key questions:

252 1. How quickly will vegetation and belowground systems shift in response to changing

253 climate, and how big will be the corresponding feedbacks to climate?

254 2. What is the role of parent material and its weathering on soil development and SOM

255 accumulation in mountain ecosystems and how is it linked to vegetation change?

256 3. To what extent can warming-induced increases in nutrient availability keep pace with the

257 increasing nutrient demands of upward shifting plant communities?

258 4. What are the key drivers of soil biota across elevation gradients, how are they linked to

259 vegetation, and what is the functional role of microbial communities in range shifts?

260 Elevational gradients document fundamental changes in the belowground system along

261 mountain slopes, while soil warming experiments frequently reveal that soil processes such

262 as increased $\mathrm{C}$ and $\mathrm{N}$ mineralization are transient, counteracted by feedbacks and difficult to

263 detect in the large soil reservoir. Reconciling these sometimes conflicting observations is

264 challenging; experiments rarely capture longer-term changes to ecosystems caused by 
turnover in species composition as range shifts occur, while gradient studies provide no

266 information about the timescales of range shifts and ecosystems changes. Yet impacts of

267 climate change on ecosystem functioning and climate feedbacks on timescales of decades to

268 centuries will be governed by the non-equilibrium dynamics occurring during range shifts.

269 There is therefore a need to bridge this gap and to better understand the rate and impacts

270 of shifts in vegetation and belowground ecosystems, using a suite of approaches.

271 Firstly and most urgently, soils and their biota should be integrated into existing monitoring

272 programs of vegetation change (e.g. $\operatorname{GLORIA}(3,52))$ and national soil inventories, setting a

273 baseline for assessing belowground changes over the coming decades. Secondly, temporal

274 changes in soil ecosystems and their interactions with vegetation might be extrapolated by

275 sampling current soils across chronosequences of vegetation changes that have been

276 documented from historical photographs, maps or satellite images, similar to studies

277 conducted on glacial forefields $(37,49)$. Thirdly, comparative studies of plant-soil

278 interactions across replicated elevation gradients within and between regions remain scarce

279 (27), yet can exploit variation in the elevational covariance between climate, soil, land-use

280 and biological communities to gain insight into drivers of ecosystem structure and function,

281 while filling data gaps in remote and understudied mountain regions. Finally, experiments

282 might be conducted that approximate non-equilibrium conditions by manipulating climate

283 and assembling the novel combinations of plants, soils and soil organisms that are expected

284 following range shifts (57), and studying their impacts on ecosystem processes, ideally in 285 combination with elevational gradient studies. 
In many respects, the belowground still represents the "Terra incognita" of mountain

288

289

290

291

293 ecosystems, and despite its importance for ecosystem functioning and global climate, the linkage between below- and aboveground ecosystems is one of the least understood research frontiers. Recent advances in molecular tools make it increasingly possible to open the "black box" of soil ecosystems, hopefully motivating renewed efforts to collect basic data on belowground process. Such information will be essential to accurately predict how current and future vegetation will interact with soil biota, soil chemistry and physics, and how these interactions will feedback to climate change.

\section{List of Figures}

Figure 1. Mountain landscapes in transition. Comparisons of present and historic photographs give evidence for the upward migration of trees to higher elevations in remote areas of the Ural mountains in response to the climatic warming in the $20^{\text {th }}$ century (from 37). The forest expansion is paralleled by changes in the belowground ecosystem.

Figure 2. Mountain ecosystems above and below the ground. Vegetation forms distinct belts across climatic gradients in elevation, spanning the nival zone with cryptogams and cushion plants, alpine grassland and heathlands, and subalpine forests $(1,2,4)$. These vegetation zones are paralleled belowground. The contribution of roots to total plant biomass typically increases with elevation (51), as perennial plants relocate resources belowground to survive harsh alpine winters. Early successional ecosystems store very little soil organic matter 
(SOM) due to low plant inputs and slow weathering (49) and host highly specific microbial taxa $(50,52,60)$. Alpine grasslands have typically high SOM contents in the topsoil as low

temperatures impede the decomposition of annual inputs of fine roots and leaf litter (45).

312 The herbaceous vegetation relies strongly on symbiotic associations with arbuscular 313 mycorrhizae for nutrient supply (60). Soils below the shrubline are characterized by a thick 314 organic layer, consisting of recalcitrant plant residues from dwarf shrubs and coniferous 315 trees $(46,47)$, with abundant ericoid and ectomycorrhizae, and free-living saprotrophs $(41$, 316 $46,54)$. The low abundance of soil fauna, especially of earthworms, impedes the physical incorporation of litter into mineral soils (48). In montane forests, the increasingly favourable 318 climate accelerates the processing of SOM, leading to a thinner organic layer $(33,37,44)$ and 319 a higher diversity and abundance of ectomycorrhizal fungi. See Table S1 for more details on 320 belowground elevational patterns.

322 Figure 3. Above- and belowground linkages in a changing climate. Mountain plants transfer 323 more than $50 \%$ of assimilated carbon (C) to roots, to associated mycorrhizal fungi in 324 exchange for soil nutrients, and to free-living bacteria and fungi feeding on rhizodeposits. 325 Within hours, photosynthetic products are allocated belowground, nourishing soil 326 organisms, and are respired back to the atmosphere as $\mathrm{CO}_{2}(14,31)$. On an annual timescale, 327 leaf and root residues enter the soils and are broken down and transformed by soil biota. 328 Only a small fraction - microbial products - are stabilized by reactive minerals formed 329 during weathering and persist in the soil for centuries to millennia (31). Consequently, soil 330 organic matter (SOM) consists of a continuum of compounds from litter to particulate soil 331 organic matter (POM) comprised of decomposing plant residues and more stable mineral332 associated organic matter $(\operatorname{MOM})(33,43)$. Climate change affects above and belowground 
333 linkages either directly through higher temperatures accelerating $C$ and nutrient cycling, or

334 indirectly as vegetation changes alter the quantity and quality of litter inputs into soils and

335 modify the microclimate. Because SOM represents the key reservoir for water and nutrients

336 and hosts soil microbial communities, changes in SOM will feedback to mountain vegetation

337 shifts in a warming climate.

338

339 Figure 4. Climate warming impacts on mountain vegetation, soils and their biota either 340 directly or indirectly through elevational shifts of plant communities. See Table S1 for 341 pertinent examples from the literature.

343 List of Supplementary Materials

344 Table S1.

345 References listed from 61 to 99 appear only in the Supplementary Materials 


\section{References:}

347 1. A. von Humboldt, A. Bonpland, Essai sur la géographie des plantes - accompagné d'un tableau physique des régions équinoxiales, fondé sur des mesures exécutées, depuis le dixième degré de latitute boréale jusqu'au dixième degré de latitute australe, pendant les années 1799, 1800, 1801, (Schoell, Paris, 1805; https://doi.org/10.3931/e-rara24316).

2. P. Moret, P. Muriel, R. Jaramillo, O. Dangles, Humboldt's Tableau Physique revisited. Proc. Natl. Acad. Sci., 201904585 (2019).

3. M. J. Steinbauer et al., Accelerated increase in plant species richness on mountain summits is linked to warming. Nature. 556, 231-234 (2018).

4. C. Körner, Alpine Plant Life (Springer Berlin Heidelberg, Berlin, Heidelberg, 2003; http://link.springer.com/10.1007/978-3-642-18970-8).

5. N. Pepin et al., Elevation-dependent warming in mountain regions of the world. Nat. Clim. Chang. 5, 424-430 (2015).

6. T. C. Parker, J.-A. Subke, P. A. Wookey, Rapid carbon turnover beneath shrub and tree vegetation is associated with low soil carbon stocks at a subarctic treeline. Glob. Chang. Biol. 21, 2070-2081 (2015).

7. P. Möhl et al., Twelve years of low nutrient input stimulates growth of trees and dwarf shrubs in the treeline ecotone. J. Ecol. 107, 768-780 (2019).

8. J. B. Fisher et al., Nutrient limitation in rainforests and cloud forests along a 3,000-m elevation gradient in the Peruvian Andes. Oecologia. 172, 889-902 (2013).

9. M. A. Dawes, P. Schleppi, S. Hättenschwiler, C. Rixen, F. Hagedorn, Soil warming opens the nitrogen cycle at the alpine treeline. Glob. Chang. Biol. 23, 421-434 (2017).

10. J. Paulsen, C. Körner, A climate-based model to predict potential treeline position 
around the globe. Alp. Bot. 124, 1-12 (2014).

371

11. E. Liang et al., Species interactions slow warming-induced upward shifts of treelines on the Tibetan Plateau. Proc. Natl. Acad. Sci. 113, 4380-4385 (2016).

12. M. A. Harsch, P. E. Hulme, M. S. McGlone, R. P. Duncan, Are treelines advancing? A global meta-analysis of treeline response to climate warming. Ecol. Lett. 12, 10401049 (2009).

13. J. Dolezal et al., Vegetation dynamics at the upper elevational limit of vascular plants in Himalaya. Sci. Rep. 6, 24881 (2016).

14. A. Ferrari, F. Hagedorn, P. A. Niklaus, Experimental soil warming and cooling alters the partitioning of recent assimilates: evidence from a ${ }^{14} \mathrm{C}$-labelling study at the alpine treeline. Oecologia. 181, 25-37 (2016).

15. S. B. Rumpf et al., Range dynamics of mountain plants decrease with elevation. Proc. Natl. Acad. Sci. 115, 1848-1853 (2018).

16. I. H. Myers-Smith, D. S. Hik, Climate warming as a driver of tundra shrubline advance. J. Ecol. 106, 547-560 (2018).

17. J. M. Alexander et al., Lags in the response of mountain plant communities to climate change. Glob. Chang. Biol. 24, 563-579 (2018).

18. S. M. Crimmins, S. Z. Dobrowski, J. A. Greenberg, J. T. Abatzoglou, A. R. Mynsberge, Changes in Climatic Water Balance Drive Downhill Shifts in Plant Species' Optimum Elevations. Science (80-. ). 331, 324-327 (2011).

19. L. Lyu et al., Drought limitation on tree growth at the Northern Hemisphere's highest tree line. Dendrochronologia. 53, 40-47 (2019).

20. P. D. Henne, C. M. Elkin, B. Reineking, H. Bugmann, W. Tinner, Did soil development limit spruce (Picea abies) expansion in the Central Alps during the Holocene? Testing a 

(2011).

21. A. Kulonen, R. A. Imboden, C. Rixen, S. B. Maier, S. Wipf, Enough space in a warmer world? Microhabitat diversity and small-scale distribution of alpine plants on mountain summits. Divers. Distrib. 24, 252-261 (2018).

22. J. HilleRisLambers, M. A. Harsch, A. K. Ettinger, K. R. Ford, E. J. Theobald, How will biotic interactions influence climate change-induced range shifts? Ann. N. Y. Acad. Sci.

401 1297 (2013), doi:10.1111/nyas.12182.

23. W. H. van der Putten, M. A. Bradford, E. Pernilla Brinkman, T. F. J. van de Voorde, G. F. 403 Veen, Where, when and how plant-soil feedback matters in a changing world. Funct.

404 Ecol. 30, 1109-1121 (2016).

405

24. K. Streit et al., Soil warming alters microbial substrate use in alpine soils. Glob. Chang. 406 Biol. 20, 1327-1338 (2014).

407

25. N. van Gestel et al., Predicting soil carbon loss with warming. Nature. 554, E4-E5 408 (2018).

26. A. T. Nottingham et al., Climate Warming and Soil Carbon in Tropical Forests: Insights from an Elevation Gradient in the Peruvian Andes. Bioscience. 65, 906-921 (2015).

27. J. R. Mayor et al., Elevation alters ecosystem properties across temperate treelines globally. Nature. 542, 91-95 (2017).

28. L. M. Kueppers et al., Warming and provenance limit tree recruitment across and beyond the elevation range of subalpine forest. Glob. Chang. Biol. 23, 2383-2395 (2017).

29. A. Schindlbacher, J. Schnecker, M. Takriti, W. Borken, W. Wanek, Microbial physiology and soil $\mathrm{CO}_{2}$ efflux after 9 years of soil warming in a temperate forest - no indications 
for thermal adaptations. Glob. Chang. Biol. 21, 4265-4277 (2015).

419

30. T. W. N. Walker et al., Microbial temperature sensitivity and biomass change explain soil carbon loss with warming. Nat. Clim. Chang. 8, 885-889 (2018).

31. M. A. Bradford et al., Managing uncertainty in soil carbon feedbacks to climate change. Nat. Clim. Chang. 6, 751-758 (2016).

32. J. Harte, S. R. Saleska, C. Levy, Convergent ecosystem responses to 23-year ambient and manipulated warming link advancing snowmelt and shrub encroachment to transient and long-term climate-soil carbon feedback. Glob. Chang. Biol. 21, 23492356 (2015).

33. M. Zimmermann, J. Leifeld, F. Conen, M. I. Bird, P. Meir, Can composition and physical protection of soil organic matter explain soil respiration temperature sensitivity? Biogeochemistry. 107, 423-436 (2012).

34. A. B. Moyes, D. R. Bowling, Interannual variation in seasonal drivers of soil respiration in a semi-arid Rocky Mountain meadow. Biogeochemistry. 113, 683-697 (2013).

35. F. Liu et al., Reduced quantity and quality of SOM along a thaw sequence on the Tibetan Plateau. Environ. Res. Lett. 13, 104017 (2018).

36. J. F. Knowles, P. D. Blanken, C. R. Lawrence, M. W. Williams, Evidence for non-steadystate carbon emissions from snow-scoured alpine tundra. Nat. Commun. 10, 1-9 (2019).

37. A. Kammer et al., Treeline shifts in the Ural mountains affect soil organic matter dynamics. Glob. Chang. Biol. 15, 1570-1583 (2009).

38. J. T. Weedon et al., Summer warming accelerates sub-arctic peatland nitrogen cycling without changing enzyme pools or microbial community structure. Glob. Chang. Biol. $18,138-150$ (2012). 
39. S. E. Hobbie, Plant species effects on nutrient cycling: revisiting litter feedbacks. Trends Ecol. Evol. 30, 357-363 (2015).

40. E. F. Solly et al., Experimental soil warming shifts the fungal community composition at the alpine treeline. New Phytol. 215, 766-778 (2017).

41. D. R. Zak et al., Exploring the role of ectomycorrhizal fungi in soil carbon dynamics. New Phytol. (2019), doi:10.1111/nph.15679.

42. R. K. Monson et al., Winter forest soil respiration controlled by climate and microbial community composition. Nature. 439, 711-714 (2006).

43. S. Doetterl et al., Soil carbon storage controlled by interactions between geochemistry and climate. Nat. Geosci. 8, 780-783 (2015).

44. S. Gosheva et al., Reconstruction of historic forest cover changes indicates minor effects on carbon stocks in Swiss forest soils. Ecosystems. 20, 1512-1528 (2017).

45. K. Budge, J. Leifeld, E. Hiltbrunner, J. Fuhrer, Alpine grassland soils contain large proportion of labile carbon but indicate long turnover times. Biogeosciences. 8, 19111923 (2011).

46. K. E. Clemmensen et al., Roots and associated fungi drive long-term carbon sequestration in boreal forest. Science. 339, 1615-1618 (2013).

47. B. Adamczyk, O.-M. Sietiö, C. Biasi, J. Heinonsalo, Interaction between tannins and fungal necromass stabilizes fungal residues in boreal forest soils. New Phytol. (2019), doi:10.1111/nph.15729.

48. A. A. Wackett, K. Yoo, J. Olofsson, J. Klaminder, Human-mediated introduction of geoengineering earthworms in the Fennoscandian arctic. Biol. Invasions. 20, 13771386 (2018).

49. R. H. Smittenberg et al., Climate-sensitive ecosystem carbon dynamics along the soil 

1941-1955 (2012).

50. D. L. Porazinska et al., Plant diversity and density predict belowground diversity and function in an early successional alpine ecosystem. Ecology. 99, 1942-1952 (2018).

470

471

472

473

474

475

476

477

478

479

480

481

482

51. G. Moser et al., Elevation effects on the carbon budget of tropical mountain forests (S Ecuador): The role of the belowground compartment. Glob. Chang. Biol. 17, 22112226 (2011).

52. M. Adamczyk et al., The Soil Microbiome of GLORIA Mountain Summits in the Swiss Alps. Front. Microbiol. 10 (2019), doi:10.3389/fmicb.2019.01080.

53. J. A. Bryant et al., Microbes on mountainsides: Contrasting elevational patterns of bacterial and plant diversity. Proc. Natl. Acad. Sci. 105, 11505-11511 (2008).

54. S. N. Kivlin, J. S. Lynn, M. R. Kazenel, K. K. Beals, J. A. Rudgers, Biogeography of plantassociated fungal symbionts in mountain ecosystems: A meta-analysis. Divers. Distrib. 23, 1067-1077 (2017).

55. C. Poeplau et al., Temporal dynamics of soil organic carbon after land-use change in the temperate zone - carbon response functions as a model approach. Glob. Chang. Biol. 17, 2415-2427 (2011).

56. L. A. Cavieres et al., Facilitative plant interactions and climate simultaneously drive alpine plant diversity. Ecol. Lett. 17, 193-202 (2014).

57. A. Cardinaux, S. P. Hart, J. M. Alexander, Do soil biota influence the outcome of novel interactions between plant competitors? J. Ecol. 106, 1853-1863 (2018).

58. M. A. Nuñez, T. R. Horton, D. Simberloff, Lack of belowground mutualisms hinders Pinaceae invasions. Ecology. 90, 2352-2359 (2009).

59. C. D. Brown, M. Vellend, Non-climatic constraints on upper elevational plant range 

(2014).

492

493

494

495

496

497

498

499

500

501

502

503

504

505

506

507

508

509

510

511

512

513

60. C. P. Bueno de Mesquita et al., Patterns of root colonization by arbuscular mycorrhizal fungi and dark septate endophytes across a mostly-unvegetated, high-elevation landscape. Fungal Ecol. 36, 63-74 (2018).

61. M. A. Dawes et al., Soil warming and $\mathrm{CO}_{2}$ enrichment induce biomass shifts in alpine tree line vegetation. Glob. Chang. Biol. 21, 2005-2021 (2015).

62. A. Anadon-Rosell et al., Xylem anatomical and growth responses of the dwarf shrub Vaccinium myrtillus to experimental $\mathrm{CO}_{2}$ enrichment and soil warming at treeline. Sci. Total Environ. 642, 1172-1183 (2018).

63. S. C. Elmendorf et al., Experiment, monitoring, and gradient methods used to infer climate change effects on plant communities yield consistent patterns. Proc. Natl. Acad. Sci. 112, 448-452 (2015).

64. E. Kaarlejärvi, A. Eskelinen, J. Olofsson, Herbivory prevents positive responses of lowland plants to warmer and more fertile conditions at high altitudes. Funct. Ecol. 27, 1244-1253 (2013).

65. J. M. Melillo et al., Soil warming, carbon-nitrogen interactions, and forest carbon budgets. Proc. Natl. Acad. Sci. 108, 9508-9512 (2011).

66. H. Majdi, J. Ohrvik, Interactive effects of soil warming and fertilization on root production, mortality, and longevity in a Norway spruce stand in Northern Sweden. Glob. Chang. Biol. 10, 182-188 (2004).

67. E. F. Solly et al., Unravelling the age of fine roots of temperate and boreal forests. Nat. Commun. 9, 1-8 (2018).

68. E. F. Solly et al., Treeline advances and associated shifts in the ground vegetation alter 

fine root dynamics and mycelia production in the South and Polar Urals. Oecologia. 183, 571-586 (2017).

69. J. M. Melillo et al., Long-term pattern and magnitude of soil carbon feedback to the climate system in a warming world. Science. 358, 101-105 (2017).

70. H. Lim et al., Boreal forest biomass accumulation is not increased by two decades of soil warming. Nat. Clim. Chang. 9, 49-52 (2019).

71. M. Väisänen et al., Consequences of warming on tundra carbon balance determined by reindeer grazing history. Nat. Clim. Chang. 4, 384-388 (2014).

72. S. B. Devi, S. S. S. S. Sherpa, Soil carbon and nitrogen stocks along the altitudinal gradient of the Darjeeling Himalayas, India. Environ. Monit. Assess. 191, 361 (2019).

73. M. G. Kramer, O. A. Chadwick, Controls on carbon storage and weathering in volcanic soils across a high-elevation climate gradient on Mauna Kea, Hawaii. Ecology. 97, 2384-2395 (2016).

74. J. D. M. Speed et al., Continuous and discontinuous variation in ecosystem carbon 528 stocks with elevation across a treeline ecotone. Biogeosciences. 12, 1615-1627 529 (2015).

75. J. Leifeld, M. Zimmermann, J. Fuhrer, F. Conen, Storage and turnover of carbon in grassland soils along an elevation gradient in the Swiss Alps. Glob. Chang. Biol. 15, 668-679 (2009).

76. E. Kolb, M. Kohlpaintner, Tangel humus forms - genesis and co-evolution with vegetation. Appl. Soil Ecol. 123, 622-626 (2018).

535 77. M. A. Dawes, P. Schleppi, F. Hagedorn, The fate of nitrogen inputs in a warmer alpine treeline ecosystem: a ${ }^{15} \mathrm{~N}$ labelling study. J. Ecol. 105, 1723-1737 (2017).

537 78. Z. Wu, P. Dijkstra, G. W. Koch, B. A. Hungate, Biogeochemical and ecological feedbacks 
79. S. Zhang et al., Impacts of altitude and position on the rates of soil nitrogen mineralization and nitrification in alpine meadows on the eastern Qinghai-Tibetan Plateau, China. Biol. Fertil. Soils. 48, 393-400 (2012).

80. L. Wang, D. L. Godbold, Soil N mineralization profiles of co-existing woody vegetation islands at the alpine tree line. Eur. J. For. Res. 136, 881-892 (2017).

81. A. P. Baldos, M. D. Corre, E. Veldkamp, Response of $\mathrm{N}$ cycling to nutrient inputs in forest soils across a 1000-3000 m elevation gradient in the Ecuadorian Andes. Ecology. 96, 749-761 (2015).

82. A. Fajardo, F. I. Piper, An assessment of carbon and nutrient limitations in the formation of the southern Andes tree line. J. Ecol. 105, 517-527 (2017).

83. A. Thébault et al., Nitrogen limitation and microbial diversity at the treeline. Oikos. 123, 729-740 (2014).

84. K. Gavazov, F. Hagedorn, A. Buttler, R. Siegwolf, L. Bragazza, Environmental drivers of carbon and nitrogen isotopic signatures in peatland vascular plants along an altitude gradient. Oecologia. 180, 257-264 (2016).

85. R. Amundson et al., Global patterns of the isotopic composition of soil and plant nitrogen. Global Biogeochem. Cycles. 17 (2003), doi:10.1029/2002GB001903.

86. C. Körner, S. Leuzinger, S. Riedl, R. T. Siegwolf, L. Streule, Carbon and nitrogen stable isotope signals for an entire alpine flora, based on herbarium samples. Alp. Bot. 126, 153-166 (2016).

87. Y. Yang, R. T. W. Siegwolf, C. Körner, Species specific and environment induced variation of $\delta^{13} \mathrm{C}$ and $\delta^{15} \mathrm{~N}$ in alpine plants. Front. Plant Sci. 6, 423 (2015).

88. C. Heer, C. Körner, High elevation pioneer plants are sensitive to mineral nutrient 

addition. Basic Appl. Ecol. 3, 39-47 (2002).

563

564

89. K. Klanderud, Species-specific responses of an alpine plant community under simulated environmental change. J. Veg. Sci. 19, 363-372 (2008).

90. B. Sveinbjornsson, O. Nordell, H. Kauhanen, Nutrient Relations of Mountain Birch Growth at and Below the Elevational Tree-Line in Swedish Lapland. Funct. Ecol. 6, 213 (1992).

91. S. Bassin, M. Volk, J. Fuhrer, Species Composition of Subalpine Grassland is Sensitive to Nitrogen Deposition, but Not to Ozone, After Seven Years of Treatment. Ecosystems. 16, 1105-1117 (2013).

92. K. E. Clemmensen, A. Michelsen, S. Jonasson, G. R. Shaver, Increased ectomycorrhizal fungal abundance after long-term fertilization and warming of two arctic tundra ecosystems. New Phytol. 171, 391-404 (2006).

93. N. Fierer et al., Microbes do not follow the elevational diversity patterns of plants and animals. Ecology. 92, 797-804 (2011).

94. J. N. Hendershot, Q. D. Read, J. A. Henning, N. J. Sanders, A. T. Classen, Consistently inconsistent drivers of microbial diversity and abundance at macroecological scales. Ecology. 98, 1757-1763 (2017).

95. I. Djukic, F. Zehetner, A. Mentler, M. H. Gerzabek, Microbial community composition and activity in different Alpine vegetation zones. Soil Biol. Biochem. 42, 155-161 (2010).

96. J. Donhauser, B. Frey, Alpine soil microbial ecology in a changing world. FEMS Microbiol. Ecol. 94, 1-31 (2018).

97. R. D. Bardgett et al., Heterotrophic microbial communities use ancient carbon following glacial retreat. Biol. Lett. 3, 487-490 (2007). 
586

587

588

589

590

591

592

593

594 funding from the Swiss National Science Foundation grant no. 171171 and K.G. was

595 supported by funding from the Swiss National Science Foundation grant no. PZ00P2_174047.

596 J.M.A. received funding from the European Union's Horizon 2020 research and innovation

597 program under grant agreement no. 678841 and from the Swiss National Science

598 Foundation grant no. 31003A_176044. Author Contributions: FH and KG conceived the

599 review, $\mathrm{FH}$ wrote the largest part of the manuscript with substantial inputs from KG and

600 JMA. KG designed the Figures with inputs from FH and JMA, while JMA conducted the final

601 editing with the support of KG and FH. Overall KG and JMA made an equal contribution and 602

603 declare that there is no competing interest.

604 

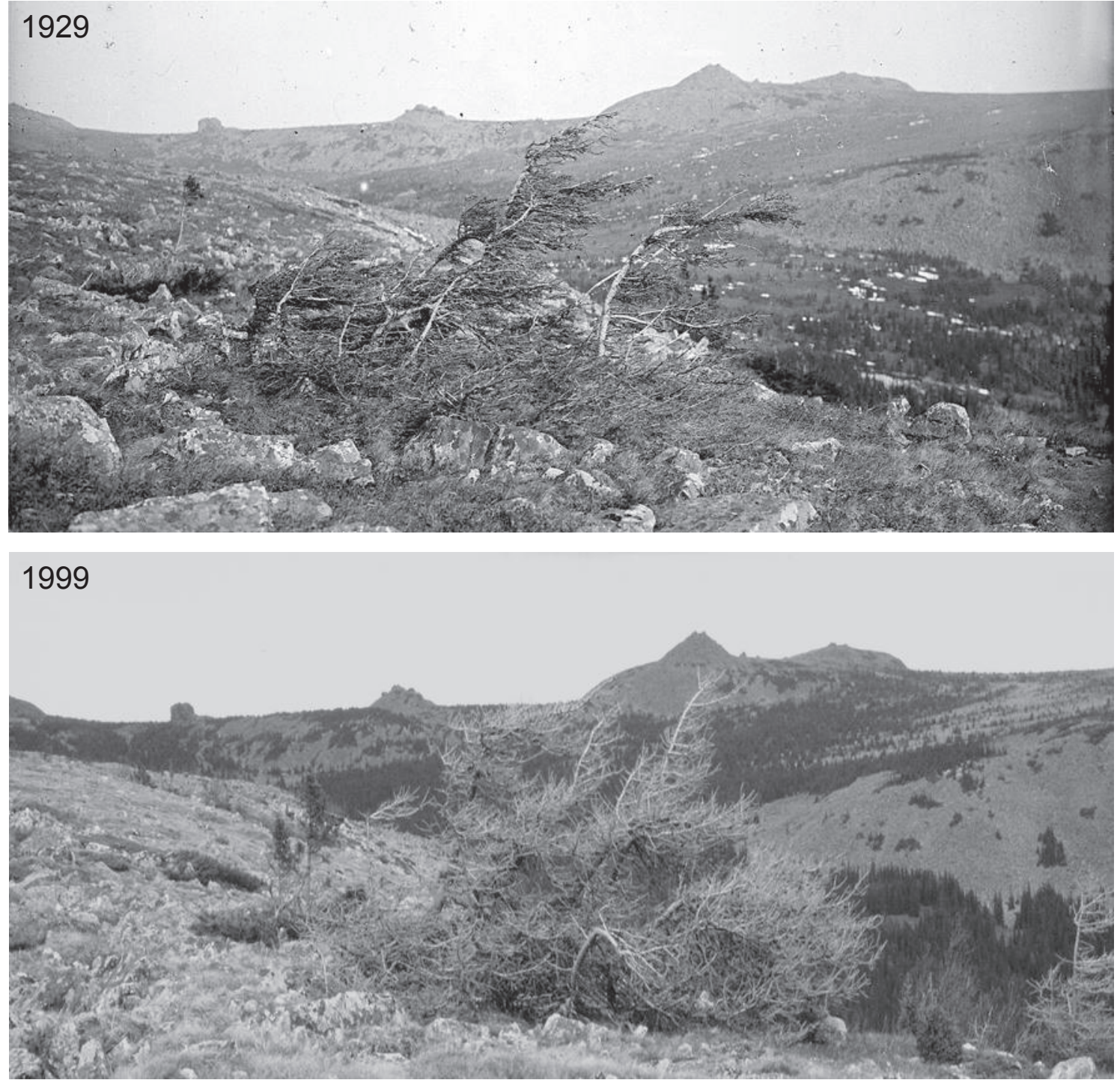

Figure 1 


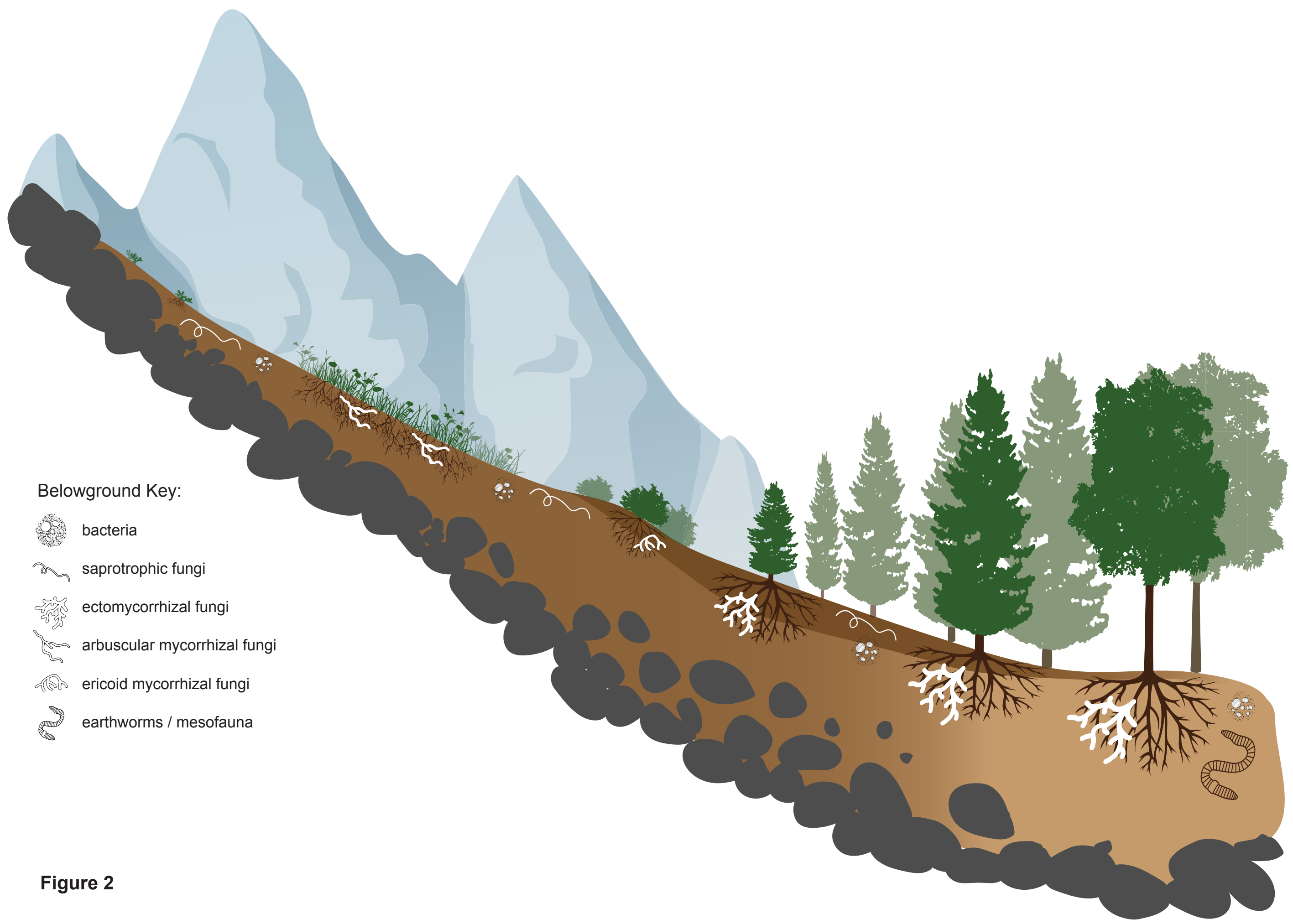




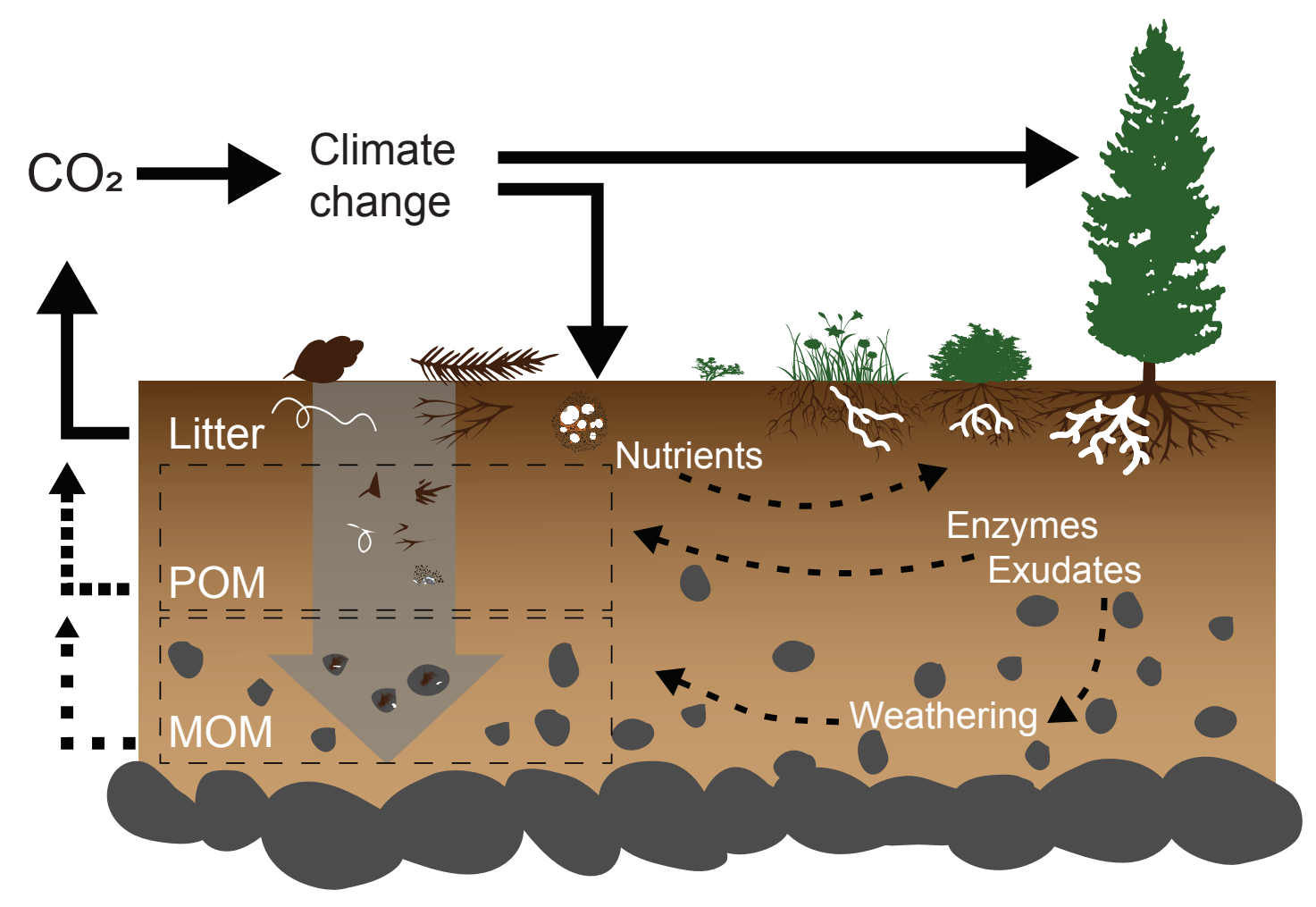

Figure 3 


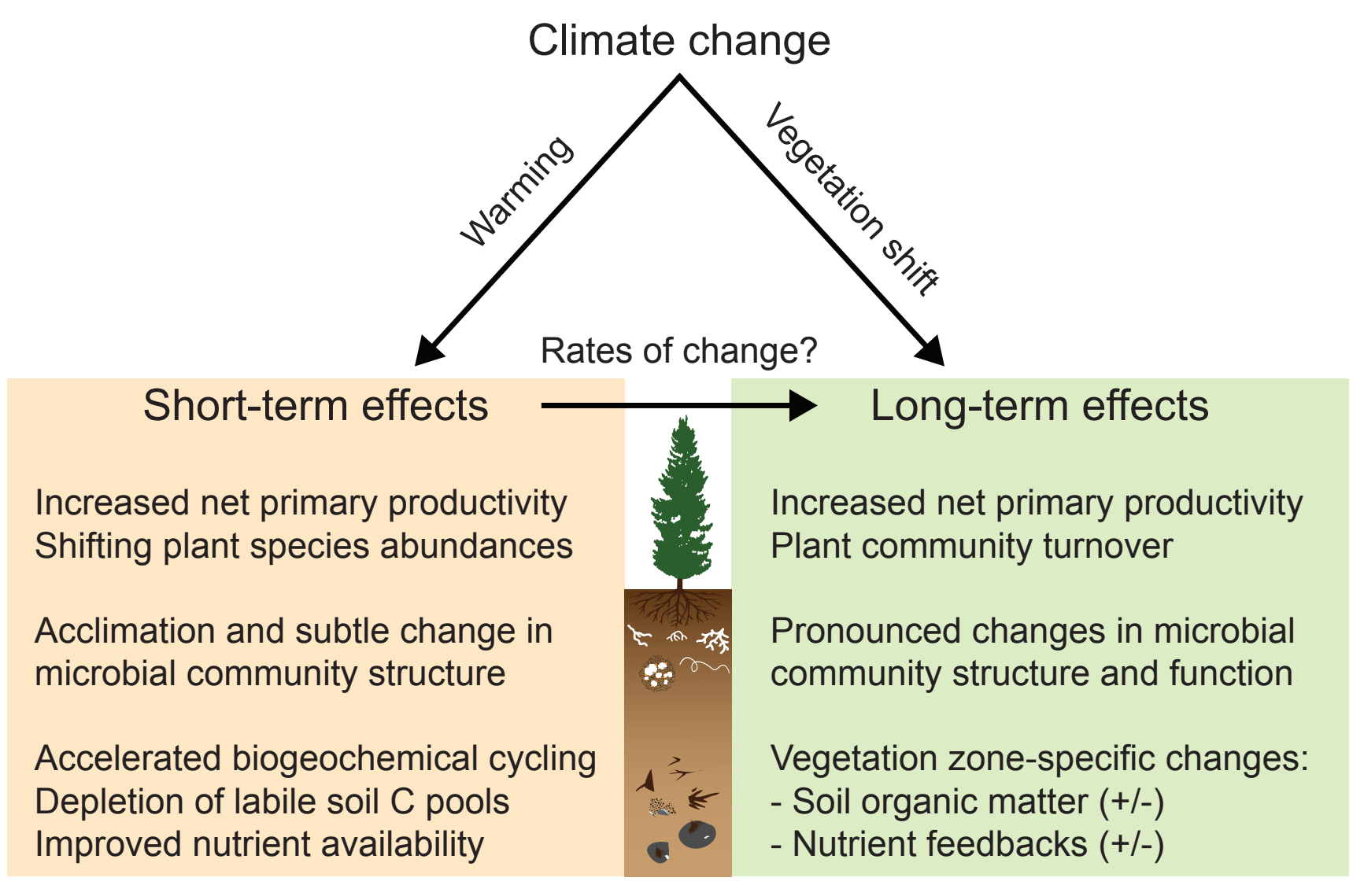

Figure 4 


\section{Science \\ DIAAAS}

\section{Supplementary Materials for}

\section{Above- and belowground linkages shape responses of mountain vegetation to climate change}

Frank Hagedorn, Konstantin Gavazov, Jake M. Alexander

correspondence to: frank.hagedorn@wsl.ch

This PDF file includes:

Tables S1 


\section{Table S1.}

Supporting examples of belowground responses to experimental manipulations and along natural gradients in mountain ecosystems or in relevant similar ecosystems. ECM, ectomycorrhizal fungi; POM, particulate organic matter; SOC, soil organic carbon; SOM, soil

organic matter.

\begin{tabular}{|c|c|c|c|c|}
\hline Parameter & Study design & Key information & $\begin{array}{l}\text { Inference on impacts of } \\
\text { vegetation shifts }\end{array}$ & Limitations and Shortcomings \\
\hline $\begin{array}{l}\text { Plant } \\
\text { productivity } \\
\text { and } \\
\text { community } \\
\text { composition }\end{array}$ & $\begin{array}{l}\text { Experimental } \\
\text { warming; } \\
\text { various } \\
\text { approaches }\end{array}$ & $\begin{array}{l}\text { Alpine meadow, Colorado; Treeline } \\
\text { (Switzerland, Colorado): } \\
\text { Thermophilization of plant communities with } \\
\text { decreased growth of forbs but increased } \\
\text { growth of shrubs and an increased } \\
\text { productivity }(32,61,62) \text { unless water is } \\
\text { limiting such as in dry mountain ranges } \\
(28) .\end{array}$ & $\begin{array}{l}\text { Warming experiments are in } \\
\text { accordance with vegetation } \\
\text { monitoring, but effect sizes are } \\
\text { smaller than along natural } \\
\text { temperature gradients }(63) \text {. }\end{array}$ & $\begin{array}{l}\text { Results are mostly short to mid-term } \\
\text { and site specific. Warming by open- } \\
\text { top chambers is small in the soil } \\
\text { (approx. } 1^{\circ} \mathrm{C} \text { ). Warming for whole } \\
\text { ecosystems by electric power is } \\
\text { experimentally difficult and thus } \\
\text { mostly confined to surface soil whilst } \\
\text { plant canopy remains non-warmed. } \\
\text { Reduced soil water content can } \\
\text { have a confounding effect. }\end{array}$ \\
\hline ---- " "--- & $\begin{array}{l}\text { Transplant } \\
\text { experiment; } \\
\text { warming; N-P- } \\
\text { K fertilization; } \\
\text { grazing } \\
\text { exclosure }\end{array}$ & $\begin{array}{l}\text { Alpine meadow, Finnish Lapland: } \\
\text { Disproportional growth of lowland plants } \\
\text { within the alpine community favoured by } \\
\text { warming and fertilization, but cancelled out } \\
\text { by grazing (64). }\end{array}$ & $\begin{array}{l}\text { Grazing limits plant range } \\
\text { expansion in elevation, but if kept } \\
\text { low, the colonised alpine } \\
\text { communities become more } \\
\text { responsive to warmer } \\
\text { temperatures and intensified } \\
\text { nutrient cycling. }\end{array}$ & $\begin{array}{l}\text { Site specific results for a set of forb } \\
\text { species only. }\end{array}$ \\
\hline Root biomass & $\begin{array}{l}\text { Soil warming } \\
\text { by heating } \\
\text { cables }\end{array}$ & $\begin{array}{l}\text { Alpine treeline: } 38 \% \text {-decrease of fine root } \\
\text { biomass after } 6 \text { years of warming }(61) \text {; } \\
\text { Hardwood forest: } 60 \% \text { decline in fine roots } \\
\text { after } 7 \text { years of warming }(65) ; \\
\text { Boreal forest: warming reduced root } \\
\text { longevity (66). }\end{array}$ & $\begin{array}{l}\text { Reduced belowground plant } \\
\text { allocation and thus smaller soil C } \\
\text { inputs. Faster root turnover may } \\
\text { partly compensate for the smaller } \\
\text { root biomass }\end{array}$ & $\begin{array}{l}\text { Results are mostly short to mid-term } \\
\text { and site specific. Warming by open- } \\
\text { top chambers is small in the soil } \\
\text { (approx. } 1^{\circ} \mathrm{C} \text { ). Warming for whole } \\
\text { ecosystems by electric power is } \\
\text { experimentally difficult and thus } \\
\text { mostly confined to surface soil whilst } \\
\text { plant canopy remains non-warmed. } \\
\text { Reduced soil water content can } \\
\text { have a confounding effect. }\end{array}$ \\
\hline
\end{tabular}




\begin{tabular}{|c|c|c|c|c|}
\hline Parameter & Study design & Key information & $\begin{array}{l}\text { Inference on impacts of } \\
\text { vegetation shifts }\end{array}$ & Limitations and Shortcomings \\
\hline Root biomass & $\begin{array}{l}\text { Elevation } \\
\text { gradient } \\
\text { across } 2000 \mathrm{~m}\end{array}$ & $\begin{array}{l}\text { Andes, mountain forests: Increase root- } \\
\text { to-shoot ratio with elevation from } 1050 \text { to } \\
3060 \mathrm{~m} \text { a.s.l., fine root productivity remains } \\
\text { constant, while aboveground productivity } \\
\text { decreases. (51). }\end{array}$ & $\begin{array}{l}\text { In relative terms C inputs into } \\
\text { soils from roots decrease with } \\
\text { decreasing elevation as } \\
\text { compared to aboveground } \\
\text { organs. These shifting C sources } \\
\text { impact microbial communities and } \\
\text { soil C stocks because root- } \\
\text { derived C is more strongly } \\
\text { stabilized in the mineral soil than } \\
\text { aboveground litter. }\end{array}$ & $\begin{array}{l}\text { Fine root production depends on } \\
\text { root longevity which is rarely } \\
\text { assessed but typically increases } \\
\text { towards colder climates (67) }\end{array}$ \\
\hline ---- " "--- & $\begin{array}{l}\text { Elevation } \\
\text { gradient } \\
\text { across treeline }\end{array}$ & $\begin{array}{l}\text { South and Polar Urals: elevational } \\
\text { increase in fine root biomass of trees and } \\
\text { ground vegetation, but decline in } \\
\text { aboveground biomass across treeline (68). }\end{array}$ & - ------ " & ---------- " ---------- \\
\hline ---- " " ---- & $\begin{array}{l}\text { Elevation } \\
\text { gradient } \\
\text { across } 2000 \mathrm{~m}\end{array}$ & $\begin{array}{l}\text { Alps: in herbaceous plants, greater relative } \\
\text { dry matter allocation to fine roots than to } \\
\text { leaves with increasing elevation (4). }\end{array}$ & ---------- " "---------- & ---------- " "--------- \\
\hline $\begin{array}{l}\text { Soil carbon } \\
\text { cycling }\end{array}$ & $\begin{array}{l}\text { Soil warming } \\
\text { by heating } \\
\text { cables }\end{array}$ & $\begin{array}{l}\text { Montane forest, Austria: } 4^{\circ} \mathrm{C} \text { soil warming: } \\
\text { increased soil } \mathrm{CO}_{2} \text { efflux }(+50 \%) \text { for at least } \\
9 \text { years without thermal adaptation of } \\
\text { microbial communities. Stimulation of both } \\
\text { root respiration and SOM mineralization } \\
(29) \text {. }\end{array}$ & $\begin{array}{l}\text { Warming accelerates SOC } \\
\text { cycling for several years, but } \\
\text { effects on soil C stocks remain } \\
\text { unclear. Soils with high SOC } \\
\text { stocks seem particularly } \\
\text { vulnerable. }\end{array}$ & $\begin{array}{l}\text { Uneven warming, reduced water } \\
\text { contents can have confounding } \\
\text { effects. }\end{array}$ \\
\hline ---- " "--- & ---- " "--- & $\begin{array}{l}\text { Alpine treeline (Switzerland): } 4^{\circ} \mathrm{C} \text { soil } \\
\text { warming: enhanced soil } \mathrm{CO}_{2} \text { efflux by } 30- \\
50 \% \text { for } 6 \text { years. Stronger acceleration of } \\
\text { SOM mineralization than root respiration ( } 9 \text {, } \\
24) \text {. }\end{array}$ & ---------- $"$ "--------- & ---------- " "---------- \\
\hline ---- " "--- & ---- " "--- & $\begin{array}{l}\text { Hardwood forest: } 5^{\circ} \mathrm{C} \text { soil warming: } \\
\text { increased soil } \mathrm{CO}_{2} \text { efflux for at least } 26 \\
\text { years. SOC loss amounted } 1.5 \mathrm{~kg} \mathrm{C} / \mathrm{m}^{2} \\
\text { (69). }\end{array}$ & $\begin{array}{l}\text { Long-term, self-reinforcing carbon } \\
\text { feedback in forests. }\end{array}$ & ---------- " "---------- \\
\hline ---- " "--- & ---- " "--- & $\begin{array}{l}\text { Boreal forest, Sweden, } 5^{\circ} \mathrm{C} \text { soil warming: } \\
\text { increase in soil } \mathrm{CO}_{2} \text { efflux was only } \\
\text { transient for about } 10 \text { years }(70) \text {. }\end{array}$ & $\begin{array}{l}\text { Limited and short-lived effect of } \\
\text { soil warming on soil } C \text { cycling }\end{array}$ & --------- " "--------- \\
\hline
\end{tabular}




\begin{tabular}{|c|c|c|c|c|}
\hline Parameter & Study design & Key information & $\begin{array}{l}\text { Inference on impacts of } \\
\text { vegetation shifts }\end{array}$ & Limitations and Shortcomings \\
\hline $\begin{array}{l}\text { Soil carbon } \\
\text { cycling }\end{array}$ & $\begin{array}{l}\text { Ecosystem } \\
\text { warming by } \\
\text { infra-red } \\
\text { heaters }\end{array}$ & $\begin{array}{l}\text { High elevation dry mountain meadow } \\
\text { (Colorado): Transient decline in SOC } \\
\text { contents for } 12 \text { years, followed by a } \\
\text { recovery due to increased shrub abundance } \\
\text { (32). }\end{array}$ & $\begin{array}{l}\text { Vegetation shift from forbs to } \\
\text { shrubs with recalcitrant litter may } \\
\text { lead to recovery of declined SOM } \\
\text { stocks following warming. }\end{array}$ & $\begin{array}{l}\text { Potentially confounding warming } \\
\text { effect by an earlier snowmelt. }\end{array}$ \\
\hline ---- " "---- & $\begin{array}{l}\text { Ecosystem } \\
\text { warming by } \\
\text { OTCs; } \mathrm{N}- \\
\text { fertilization; } \\
\text { grazing } \\
\text { exclosure }\end{array}$ & $\begin{array}{l}\text { Alpine meadow, Finnish Lapland: } \\
\text { warming decreases ecosystem C sink } \\
\text { strength in lightly grazed alpine heath, but } \\
\text { has no effect in heavily grazed alpine } \\
\text { grassland, which is a weaker sink than } \\
\text { heath (71). }\end{array}$ & $\begin{array}{l}\text { Grazing-induced vegetation shifts } \\
\text { can overarch warming impacts on } \\
\text { C-cycling, but the direction of the } \\
\text { response is the same. }\end{array}$ & $\begin{array}{l}\text { Seasonal } \mathrm{CO}_{2} \text { fluxes do not reflect } \\
\text { above and belowground stocks and } \\
\text { their long-term responses. }\end{array}$ \\
\hline $\begin{array}{l}\text { Soil organic } \\
\text { matter stocks }\end{array}$ & $\begin{array}{l}\text { Elevation } \\
\text { gradient } \\
\text { across }>1500 \\
\mathrm{~m}, \text { natural } \\
\text { ecosystems }\end{array}$ & $\begin{array}{l}\text { Total SOC stocks increase from low } \\
\text { elevation forests to shrubline, in particular in } \\
\text { organic layer. } \\
\text { Andes: SOC stocks increase across } 100 \mathrm{~m} \\
\text { in elevation by } 1 \mathrm{~kg} \mathrm{C} / \mathrm{m}^{2}(26) ; \\
\text { Himalaya: increase along } 100 \mathrm{~m} \text { in } \\
\text { elevation by } 0.9 \mathrm{~kg} \mathrm{C} / \mathrm{m}^{2}(72) ; \\
\text { Swiss Alps, } 1000 \text { forest soil profiles: SOC } \\
\text { increase towards treeline by } 0.45 \mathrm{~kg} / \mathrm{m}^{2} \text { per } \\
100 \mathrm{~m} \text { in elevation (44). } \\
\text { Colorado, Alps, Hawaii: Above treeline, } \\
\text { SOC stocks decline towards nival zone, } \\
\text { where SOC is negligible on rocky terrain } \\
(50,52,73) \text {. }\end{array}$ & $\begin{array}{l}\text { Soil C is likely lost from soils with } \\
\text { upward shifts of forested zones } \\
\text { as opposed to } C \text { gains with } \\
\text { ecosystem development below } \\
\text { nival zone. }\end{array}$ & $\begin{array}{l}\text { Rates of change and underlying } \\
\text { mechanisms remain uncertain. } \\
\text { Drivers are difficult to disentangle, } \\
\text { temperature gradient with elevation } \\
\text { is frequently confounded with } \\
\text { precipitation, and outcome could be } \\
\text { biased by changing conditions other } \\
\text { than climate (parent material, slope, } \\
\text { erosion, land-use). Site selection is } \\
\text { also critical. SOM pool sizes } \\
\text { considering soil density and stone } \\
\text { contents have hardly been } \\
\text { quantified above treeline. }\end{array}$ \\
\hline $\begin{array}{l}\text { Soil organic } \\
\text { matter stocks }\end{array}$ & $\begin{array}{l}\text { Elevation } \\
\text { gradient } \\
\text { across } \\
\text { treeline; } \\
\text { grazing } \\
\text { exclosure }\end{array}$ & $\begin{array}{l}\text { South Norway treeline: Higher organic } \\
\text { horizon SOC stocks above treeline, but no } \\
\text { difference in mineral horizon across } \\
\text { elevations. No effect of } 12 \text { year intensified } \\
\text { grazing pressure (74). }\end{array}$ & $\begin{array}{l}\text { Forest expansion in elevation } \\
\text { would lead to SOC losses from } \\
\text { labile organic horizons. Neither } \\
\text { above-, nor belowground C } \\
\text { stocks along the gradient are } \\
\text { affected by grazing. }\end{array}$ & $\begin{array}{l}\text { Uncertain relative importance of } \\
\text { browsing versus grazing } \\
\text { mammalian herbivory for shaping } \\
\text { treeline ecotones. }\end{array}$ \\
\hline
\end{tabular}




\begin{tabular}{|c|c|c|c|c|}
\hline Parameter & Study design & Key information & $\begin{array}{l}\text { Inference on impacts of } \\
\text { vegetation shifts }\end{array}$ & Limitations and Shortcomings \\
\hline $\begin{array}{l}\text { Soil organic } \\
\text { matter } \\
\text { composition }\end{array}$ & $\begin{array}{l}\text { Elevation } \\
\text { gradient } \\
\text { across }>1500 \\
\mathrm{~m}, \\
\text { grassland, } \\
\text { forests }\end{array}$ & $\begin{array}{l}\text { Andes, tropical montane forests: POM } \\
\text { increases from } 5 \% \text { at } 1000 \mathrm{~m} \text { a.s.I. to } 40 \% \\
\text { at } 3000 \mathrm{~m} \text { a.s.I. }(26,33) . \\
\text { Swiss Alps: Contribution of POM in } \\
\text { grassland soils }(0-20 \mathrm{~cm}) \text { and in forest soils } \\
(0-100 \mathrm{~cm}) \text { increase from } 10 \% \text { at } 400 \mathrm{~m} \\
\text { a.s.l. to } 50 \% \text { at } 2400 \mathrm{~m} \text { a.s.I. }(44,45,75) \text {. } \\
\text { The mean residence time of POM (based } \\
\left.\text { on }{ }^{14} \mathrm{C}\right) \text { also increases with elevation (45). } \\
\text { On non-weathered bedrock, there are up to } \\
100 \mathrm{~cm} \text { thick organic horizons in the Alps } \\
\text { (classified as 'Tangel') (76). }\end{array}$ & $\begin{array}{l}\text { As POM represents labile SOM, } \\
\text { high POM contents in mountain } \\
\text { soils imply a high vulnerability. } \\
\text { The decline in POM towards } \\
\text { lower elevation/warmer climate } \\
\text { reflects a loss in POM, resulting in } \\
\text { smaller SOM stocks that are less } \\
\text { decomposable. POM potentially } \\
\text { represents SOM pool that } \\
\text { becomes depleted in soil warming } \\
\text { experiments. }\end{array}$ & $\begin{array}{l}\text { Rates of change and underlying } \\
\text { mechanisms remain uncertain. } \\
\text { Drivers are difficult to disentangle }\end{array}$ \\
\hline $\begin{array}{l}\text { Nitrogen } \\
\text { cycling }\end{array}$ & $\begin{array}{l}\text { Experimental } \\
\text { warming by } \\
\text { open-top } \\
\text { chambers }\end{array}$ & $\begin{array}{l}\text { Sub-arctic mountain peatland, } 9 \text { year } \\
\text { warming: doubling of extractable organic } \\
\text { and mineral } N(38) \text {. }\end{array}$ & $\begin{array}{l}\text { Accelerated } \mathrm{N} \text {-cycling in warmer } \\
\text { soils improves } \mathrm{N} \text { availability and } \\
\text { plant growth }\end{array}$ & $\begin{array}{l}\text { Potential interaction with water } \\
\text { status; mid-term nature }\end{array}$ \\
\hline ----- " "---- & $\begin{array}{l}\text { Soil warming } \\
\text { by heating } \\
\text { cables }\end{array}$ & $\begin{array}{l}\text { Alpine treeline, } 6 \text { year soil warming: } \\
\text { transient increase in mineral } N(+100 \%) \text {, } \\
\text { declining response resulted from enhanced } \\
\text { plant } N \text { uptake. }{ }^{15} \mathrm{~N} \text { tracer experiment } \\
\text { showed sustained increase in } \mathrm{N} \\
\text { mineralization by warming }(9,77) .\end{array}$ & $\begin{array}{l}\text { Improved N-availability in warmer } \\
\text { soils }\end{array}$ & --------- " --------- \\
\hline $\begin{array}{l}\text { Nitrogen } \\
\text { cycling, } \\
\text { Plant } \\
\text { communities }\end{array}$ & $\begin{array}{l}\text { Transplant } \\
\text { experiment }\end{array}$ & $\begin{array}{l}\text { Arizona, } 4 \text { grassland communities from } \\
\text { dessert to high montane: Warming caused } \\
\text { encroachment by species typical of warmer } \\
\text { environments. Ephemeral stimulation of } \\
\text { plant productivity by enhanced } N \text { availability } \\
\text { which declined with time }(78) \text {. }\end{array}$ & $\begin{array}{l}\text { Improved N-availability in warmer } \\
\text { soils likely contributing to } \\
\text { enhanced plant growth }\end{array}$ & $\begin{array}{l}\text { Vegetation shift influenced by } \\
\text { adjacent plant communities. } \\
\text { Transplant disturbs plant and soil } \\
\text { system. }\end{array}$ \\
\hline $\begin{array}{l}\text { Nitrogen } \\
\text { mineralization }\end{array}$ & $\begin{array}{l}\text { Elevation } \\
\text { gradient } \\
\text { across } 1000 \\
\mathrm{~m}, \text { grassland }\end{array}$ & $\begin{array}{l}\text { Alpine grasslands, Tibet: Doubling of in } \\
\text { situ } \mathrm{N} \text { mineralization along an elevational } \\
\text { decrease of } 1000 \mathrm{~m}(79) .\end{array}$ & $\begin{array}{l}\text { Nitrogen supply for plant } \\
\text { communities improves in a } \\
\text { warming climate. }\end{array}$ & $\begin{array}{l}\text { Short-term experiment. Inference to } \\
\text { annual scale uncertain. }\end{array}$ \\
\hline
\end{tabular}




\begin{tabular}{|c|c|c|c|c|}
\hline Parameter & Study design & Key information & $\begin{array}{l}\text { Inference on impacts of } \\
\text { vegetation shifts }\end{array}$ & Limitations and Shortcomings \\
\hline $\begin{array}{l}\text { Nitrogen } \\
\text { mineralization }\end{array}$ & $\begin{array}{l}\text { Elevation } \\
\text { gradient } \\
\text { across treeline }\end{array}$ & $\begin{array}{l}\text { South Urals: Potential } \mathrm{N} \text { mineralization } \\
\text { more than doubles from tundra to closed } \\
\text { forest (37). }\end{array}$ & $\begin{array}{l}\text { Potential N mineralization } \\
\text { increases when forests expand } \\
\text { into alpine shrubland. }\end{array}$ & $\begin{array}{l}\text { Short-term laboratory experiment. } \\
\text { Inference to annual scale difficult. }\end{array}$ \\
\hline ---- " "--- & At treeline & $\begin{array}{l}\text { Austrian treeline: greater in situ } \\
\text { mineralization under coniferous treeline } \\
\text { trees than under Rhododendron shrubs } \\
(80) \text {. }\end{array}$ & $\begin{array}{l}\mathrm{N} \text { mineralization is species- } \\
\text { dependent. }\end{array}$ & Short term in situ study. \\
\hline ---- " "--- & $\begin{array}{l}\text { Elevation } \\
\text { gradient } \\
\text { across } 2000 \mathrm{~m}\end{array}$ & $\begin{array}{l}\text { Andes, montane forest: Strong increase in } \\
\mathrm{N} \text { mineralization and transformation with } \\
\text { decreasing elevation (81). }\end{array}$ & $\begin{array}{l}\text { Faster } \mathrm{N} \text { cycling and potentially } \\
\text { greater } \mathrm{N} \text { plant supply in warmer } \\
\text { climate. }\end{array}$ & $\begin{array}{l}\text { Short-term }{ }^{15} \mathrm{~N} \text {-based assays within } \\
\text { longer term fertilization experiments. }\end{array}$ \\
\hline $\begin{array}{l}\text { Mineral, plant } \\
\text { available N }\end{array}$ & $\begin{array}{l}\text { Elevation } \\
\text { gradient } \\
\text { across treeline }\end{array}$ & $\begin{array}{l}\text { Treeline, temperate zone: Mineral (=plant } \\
\text { available) } \mathrm{N} \text { pool increases across treeline } \\
\text { from the alpine to forest in } 5 \text { out } 7 \text { regions } \\
(27) . \mathrm{N} \text { binding in biomass also increases } \\
\text { strongly } \\
\text { South and Polar Urals: Doubling of } \\
\text { mineral } \mathrm{N} \text { contents from tundra to closed } \\
\text { forest }(68) \text {. Patagonia: increase of mineral } \\
\mathrm{N} \text { by } 60 \% \text { along } 4 \text { elevational gradients } \\
(300-500 \mathrm{~m} \text { in elevation) from treeline } \\
\text { towards subalpine forests ( } 82) \text { and from } \\
\text { subalpine forests to the alpine zone (83). }\end{array}$ & $\begin{array}{l}\text { Nitrogen availability for plant } \\
\text { communities increases when } \\
\text { forests are expanding to alpine } \\
\text { shrubs. }\end{array}$ & $\begin{array}{l}\text { Instantaneous measurement, net } \\
\text { effect from } \mathrm{N} \text { mineralization and } \\
\text { plant } \mathrm{N} \text { uptake }\end{array}$ \\
\hline $\begin{array}{l}{ }^{15} \mathrm{~N} \text { natural } \\
\text { abundance } \\
\text { as an } \\
\text { indicator of } \mathrm{N} \\
\text { availability }\end{array}$ & $\begin{array}{l}\text { Elevation } \\
\text { gradient } \\
\text { at various } \\
\text { scales and } \\
\text { global patterns }\end{array}$ & $\begin{array}{l}\text { Andes, montane forests } 1000 \text { to } 3000 \mathrm{~m} \\
\text { a.s.I.: Broader scale decrease in } \delta^{15} \mathrm{~N} \\
\text { values with increasing elevation }(81) ; \\
\text { South and Polar Urals: increase in } \delta^{15} \mathrm{~N} \\
\text { values in fine roots from tundra to forest } \\
\text { (68); } \\
\text { Swiss Alps, peatlands: increase in } \delta^{15} \mathrm{~N} \\
\text { values in foliage of ericoid shrubs }(84) ;\end{array}$ & $\begin{array}{l}{ }^{15} \mathrm{~N} \text { natural abundance in plants is } \\
\text { a measure of } \mathrm{N} \text { availability and } \\
\text { plant nitrogen uptake via } \\
\text { mycorrhizal associations. } \\
\text { Elevational patterns in } \delta^{15} \mathrm{~N} \\
\text { values shows improving } \mathrm{N} \\
\text { availability for plants toward lower } \\
\text { elevation ecosystems. }\end{array}$ & $\begin{array}{l}\delta^{15} \mathrm{~N} \text { value is only an indicator for } \\
\text { nitrogen uptake via mycorrhizal } \\
\text { associations. }\end{array}$ \\
\hline
\end{tabular}




\begin{tabular}{|c|c|c|c|c|}
\hline Parameter & Study design & Key information & $\begin{array}{l}\text { Inference on impacts of } \\
\text { vegetation shifts }\end{array}$ & Limitations and Shortcomings \\
\hline $\begin{array}{l}{ }^{15} \mathrm{~N} \text { natural } \\
\text { abundance }\end{array}$ & $\begin{array}{l}\text { Global } \\
\text { patterns }\end{array}$ & $\begin{array}{l}\text { Global latitudinal pattern corresponds } \\
\text { with elevation gradients that show } \\
\text { decreasing } \delta^{15} \mathrm{~N} \text { values towards colder } \\
\text { climates }(85) .\end{array}$ & $\begin{array}{l}\text { Improving } \mathrm{N} \text { availability for plants } \\
\text { in a warming climate }\end{array}$ & \\
\hline ---- " "--- & $\begin{array}{l}\text { Alpine } \\
\text { vegetation, site } \\
\text { differences }\end{array}$ & $\begin{array}{l}\text { Alpine vegetation: } \delta^{15} \mathrm{~N} \text { value in alpine } \\
\text { plants show large differences among plant } \\
\text { species and plant functional groups } \\
\text { reflecting different pathways of nitrogen } \\
\text { uptake from soils (e.g. via symbiotic fungi). } \\
\text { Differences among sites (heath, meadow, } \\
\text { snow beds) }(86,87) \text {. }\end{array}$ & $\begin{array}{l}\text { Intimate linkage of site and soil } \\
\text { properties, } \mathrm{N} \text { availability and plant } \\
\text { communities. }\end{array}$ & ---------- " "---------- \\
\hline $\begin{array}{l}\text { Nutrient } \\
\text { limitation of } \\
\text { plant } \\
\text { communities }\end{array}$ & $\begin{array}{l}\mathrm{N}-\mathrm{P}-\mathrm{K} \\
\text { fertilization } \\
\text { experiments to } \\
\text { test for nutrient } \\
\text { limitation }\end{array}$ & $\begin{array}{l}\text { High elevation pioneer vegetation in } \\
\text { Swiss Alps: Fertilization more than } \\
\text { doubled biomass production in early and } \\
\text { late successional system, responses were } \\
\text { species specific (88). }\end{array}$ & $\begin{array}{l}\text { Changes in microbial driven } \\
\text { nutrient mineralization by an } \\
\text { altered microclimate will strongly } \\
\text { impact plant growth and diversity }\end{array}$ & $\begin{array}{l}\text { Effect of individual nutrients remains } \\
\text { unknown. }\end{array}$ \\
\hline ---- " "--- & ---- " ---- & $\begin{array}{l}\text { Dryas heath, Norway: Nutrient addition } \\
\text { combined with warming increased the } \\
\text { abundance of high stature species, such as } \\
\text { grasses and forbs, while low stature forbs } \\
\text { and most bryophytes and lichens decreased } \\
\text { in abundance (89). }\end{array}$ & $\begin{array}{l}\text { Changes in microbial driven } \\
\text { nutrient mineralization by an } \\
\text { altered microclimate will strongly } \\
\text { impact plant growth and diversity }\end{array}$ & $\begin{array}{l}\text { Fertilization effect was greater than } \\
\text { effect of open-top chambers with a } \\
\text { small warming effect }\end{array}$ \\
\hline ---- " "--- & ---- " ---- & $\begin{array}{l}\text { Treeline in Swiss Alps: Growth } \\
\text { enhancement of } 2 \text { tree species and } \\
\text { understory vegetation to } 12 \text { years of N-P-K } \\
\text { fertilization at low dose ( } 15 \mathrm{~kg} \mathrm{~N} / \mathrm{ha} / \mathrm{y})(7) \text {. }\end{array}$ & $\begin{array}{l}\text { Increased } \mathrm{N} \text { mineralization in } \\
\text { warmer soils will promote forest } \\
\text { growth and potentially forest } \\
\text { expansion. }\end{array}$ & $\begin{array}{l}\text { Effect of individual nutrients remains } \\
\text { unknown. }\end{array}$ \\
\hline ---- " "--- & ---- " " ---- & $\begin{array}{l}\text { Treeline and subalpine forest in Sub- } \\
\text { Arctic: Greater responsiveness of treeline } \\
\text { than valley forests to high dose fertilization } \\
(90) \text {. }\end{array}$ & ---------- " " ---------- & ----- " \\
\hline ---- " "--- & $\begin{array}{l}\mathrm{N} \text { fertilization } \\
\text { experiment } \\
\text { with various } \\
\text { doses }\end{array}$ & $\begin{array}{l}\text { Subalpine grassland in Swiss Alps: } \\
\text { Above-ground productivity and altered } \\
\text { species composition at doses }>5 \mathrm{~kg} \mathrm{~N} / \mathrm{ha} / \mathrm{y} \\
(91) \text {. }\end{array}$ & $\begin{array}{l}\text { Small warming-induced changes } \\
\text { in } \mathrm{N} \text { availability will affect alpine } \\
\text { plant communities. }\end{array}$ & $\begin{array}{l}\text { Indirect effects of warming via } \\
\text { nutrient mineralization availability } \\
\text { cannot be quantified. }\end{array}$ \\
\hline
\end{tabular}




\begin{tabular}{|c|c|c|c|c|}
\hline Parameter & Study design & Key information & $\begin{array}{l}\text { Inference on impacts of } \\
\text { vegetation shifts }\end{array}$ & Limitations and Shortcomings \\
\hline $\begin{array}{l}\text { Plant nutrient } \\
\text { limitation }\end{array}$ & $\begin{array}{l}\mathrm{N} \text { and } \mathrm{P} \\
\text { fertilization } \\
\text { experiment }\end{array}$ & $\begin{array}{l}\text { Cloud and rain forest, Andes: } \mathrm{N} \text { and } \mathrm{P} \\
\text { fertilization shows increasing } \mathrm{N} \text { limitation } \\
\text { with increasing elevation (8). }\end{array}$ & $\begin{array}{l}\text { High elevation system is primarily } \\
\mathrm{N} \text { limited. }\end{array}$ & ---------- " "--------- \\
\hline $\begin{array}{l}\text { Soil microbial } \\
\text { communities }\end{array}$ & $\begin{array}{l}\text { Experimental } \\
\text { warming } \\
\text { various } \\
\text { approaches }\end{array}$ & $\begin{array}{l}\text { Decreases in microbial biomass }(24,29, \\
30), \text { but limited effect on microbial } \\
\text { community structure }(29,30) \text {. DNA-based } \\
\text { analysis show shifts in fungal communities } \\
\text { towards nitrophilous species }(40) ; \text { greater } \\
\text { abundance of } N \text {-favoring ECM }(92) \text {, but } \\
\text { warming effects are small compared to } \\
\text { difference between soil horizons and among } \\
\text { plant species in the plots. }\end{array}$ & $\begin{array}{l}\text { Species shift in fungal } \\
\text { communities affect } \mathrm{C} \text { and } \mathrm{N} \\
\text { cycling }\end{array}$ & $\begin{array}{l}\text { Potentially confounding warming } \\
\text { effect by an earlier snowmelt. }\end{array}$ \\
\hline $\begin{array}{l}\text { Soil microbial } \\
\text { communities }\end{array}$ & $\begin{array}{l}\text { Global pattern } \\
\text { and elevation } \\
\text { gradient } \\
\text { across more } \\
\text { than } 2000 \mathrm{~m} \text { in } \\
\text { elevation }\end{array}$ & $\begin{array}{l}\text { Global elevational and latitudinal patterns in } \\
\text { microbial and plant diversity do not run in } \\
\text { parallel }(93,94) \text {. } \\
\text { Andes: Microbial diversity increases with } \\
\text { elevation from lowlands to shrubline (93); } \\
\text { Swiss Alps: decrease in microbial diversity } \\
\text { towards nival zone (52). } \\
\text { The contribution of fungi to microbial } \\
\text { biomass increases with elevation in forests } \\
\text { (Andes (26)), but decrease towards the } \\
\text { shrubzone and alpine grasslands (Austria } \\
\text { (95)). } \\
\text { Soils from early successional ecosystems } \\
\text { already contain high diversity (50), and } \\
\text { show an initial dominance of soil bacteria } \\
\text { (96) and an increasing contribution of fungi } \\
\text { with ecosystem development (97). }\end{array}$ & $\begin{array}{l}\text { Microbial communities are linked } \\
\text { to vegetation zones either directly } \\
\text { or indirectly by SOM. Changes in } \\
\text { microbial community structure } \\
\text { feedback on plant growth. }\end{array}$ & $\begin{array}{l}\text { Estimates are potentially biased by } \\
\text { considering surface soils only and } \\
\text { not quantifying pool sizes per } \\
\text { surface area. Only a small part of } \\
\text { microbial species is known, their } \\
\text { functions remain uncertain and are } \\
\text { frequently redundant among } \\
\text { species. }\end{array}$ \\
\hline ---- " "--- & $\begin{array}{l}\text { Global } \\
\text { patterns }\end{array}$ & $\begin{array}{l}\text { Microbial biomass correlates with soil } \\
\text { organic carbon content }(52,95) \text {, while } \\
\text { diversity is primarily linked to soil C:N } \\
\text { (fungi) and soil pH (bacteria) }(98,99) \text {. }\end{array}$ & $\begin{array}{l}\text { Accumulation of soil organic } \\
\text { matter and parent material exert } \\
\text { dominant influence on soil } \\
\text { microbial community structure }\end{array}$ & $\begin{array}{l}\text { Direct linkage of microbial and plant } \\
\text { communities remains hidden and is } \\
\text { difficult to identify. }\end{array}$ \\
\hline
\end{tabular}

